\title{
Letter to the Editor: COVID-19 vaccine during pregnancy: it is time to have a fair inclusion of pregnant women in clinical trials
}

\author{
Elisabetta Gragnano (D), Gennaro Esposito (D), Bernadette llardi (iD, Maddalena Turco (D), \\ Paolo Verrazzo (iD, Gabriele Saccone (D) \\ University of Naples Federico II, Naples, Italy
}

\section{Dear Editor,}

Currently, there is an ongoing debate on COVID-19 vaccines in pregnancy. A Practice Advisory was developed by the American College of Obstetricians and Gynecologists (ACOG) Immunization, Infectious Disease, and Public Health Preparedness Expert Work Group.$^{[1]}$ Based on this advisory, ACOG recommended that COVID-19 vaccines should not be withheld from pregnant individuals who meet criteria for vaccination based on the Advisory Committee on Immunization Practices (ACIP) recommended priority groups.

ACOG also stated that COVID-19 vaccines should be offered to lactating patients similar to non-lactating ones. Instead, before the recommendation stated by ACOG, the World Health Organization (WHO) admitted that while pregnancy puts women at higher risk of severe COVID-19, very little data are available to assess vaccine safety in pregnancy.

On January 8 2021, the WHO's Strategic Advisory Group of Experts on Immunization (SAGE) has issued its policy recommendations for the rollout of the first COVID-19 vaccine approved for emergency use, the Pfizer-BioNTech COVID-19 vaccine. ${ }^{[2]}$ In this recommendations the SAGE stated clearly that, due to insufficient data, 'WHO does not recommend the vaccination of pregnant women at this time'. ${ }^{[2]}$ Surprisingly, the same group published Interim recommendations for use of the Moderna mRNA-1273 vaccine against COVID$19^{[3]}$ where stated, on January 26, 2021 that 'Based on what we know about this kind of vaccine, we don't have any specific reason to believe there will be specific risks that would outweigh the benefits of vaccination for pregnant women. For this reason, those pregnant women at high risk of exposure to SARS-CoV-2 (e.g. health workers) or who have comorbidities which add to their risk of severe disease, may be vaccinated in consultation with their health care provider. ${ }^{[3]}$

The development of drugs and vaccine is a slow process, and all the phases involved in their development are necessary to test for safety and efficacy in different subgroups of population. Unfortunately, pregnant women are often underrepresented in clinical research and excluded from trials solely for their pregnancy status. In fact, pregnant women have been excluded from all trials on COVID-19 vaccine. ${ }^{[4]}$

Conflicting recommendations are confusing for both health care providers and for pregnant women and may also incite conspiration and no vax theories. In our opinion, therefore, first, evidence-based data are needed, such as urgent call for pregnant women to be included in appropriately designed vaccine trials and clinical studies. Moreover, we recommend to all societies to be consistent in recommendations and publish joint advisories.

Correspondence: Elisabetta Gragnano, MD. University of Naples Federico II, Naples, Italy.

e-mail: elisabettagragnano@gmail.com / Received: October 6, 2021; Accepted: November 5, 2021

How to cite this article: Gragnano E, Esposito G, Ilardi B, Turco M, Verrazzo P, Saccone G. Letter to the Editor: COVID-19 vaccine during pregnancy: it is time to have a fair inclusion of pregnant women in clinical trials. Perinatal Journal 2021;29(3):274-275. doi:10.2399/prn.21.0293001 
Funding: This work did not receive any specific grant from funding agencies in the public, commercial, or not-for-profit sectors.

Compliance with Ethical Standards: The authors stated that the standards regarding research and publication ethics, the Personal Data Protection Law and the copyright regulations applicable to intellectual and artistic works are complied with and there is no conflict of interest.

\section{References}

1. ACOG. Vaccinating pregnant and lactating patients against COVID-19. Practice advisory [Internet]. Washington, DC: American College of Obstetricians and Gynecologists; 2020 Dec [updated 2021 Mar 4] Available from: https://obgyn.uw. edu/news/vaccinating-pregnant-and-lactating-patients-against-covid-19
2. WHO's Strategic Advisory Group of Experts on Immunization (SAGE). Who can take the Pfizer-BioNTech COVID-19 vaccine? [Internet]. Geneva: WHO; 2021 Sep 2 [updated 2021 Jun 25] Available from: https://www.who.int/news-room/featurestories/detail/who-can-take-the-pfizer-biontech-covid-19-vaccine

3. WHO's Strategic Advisory Group of Experts on Immunization (SAGE). The Moderna COVID-19 (mRNA$1273)$ vaccine: what you need to know [Internet]. Geneva: WHO; 2021 Sep 2 [updated 2021 Jun 25] Available from: https://www.who.int/news-room/feature-stories/detail/themoderna-covid-19-mrna-1273-vaccine-what-you-need-toknow

4. Saccone G, Zullo F, Di Mascio D. Coronavirus disease 19 vaccine in pregnant women: not so far! The importance of counseling and the need for evidence-based data. Am J Obstet Gynecol MFM 2021;3(3):100324. [PubMed] [CrossRef]

This work is licensed under the Creative Commons Attribution-NonCommercial-NoDerivs 4.0 Unported (CC BY-NC-ND4.0) License. To view a copy of this license, visit http://creativecommons.org/licenses/by-nc-nd/4.0/ or send a letter to Creative Commons, PO Box 1866, Mountain View, CA 94042 , USA.

Publisher's Note: The content of this publication does not necessarily reflect the views or policies of the publisher, nor does any mention of trade names, commercial products, or organizations imply endorsement by the publisher. Scientific and legal responsibilities of published manuscript belong to their author(s). The publisher remains neutral with regard to jurisdictional claims in published maps and institutional affiliations. 